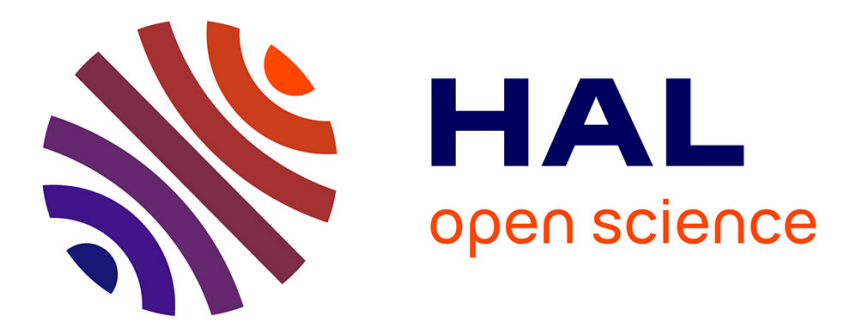

\title{
Climatic response of ring width and maximum latewood density of Larix sibirica in the Altay Mountains, reveals recent warming trends
}

\author{
Chen, Yuan, Wei, Fan, Shang, Zhang, Yu, Ji, Qin
}

\section{- To cite this version:}

Chen, Yuan, Wei, Fan, Shang, et al.. Climatic response of ring width and maximum latewood density of Larix sibirica in the Altay Mountains, reveals recent warming trends. Annals of Forest Science, 2012, 69 (6), pp.723-733. 10.1007/s13595-012-0187-2 . hal-00930837

\section{HAL Id: hal-00930837 https://hal.science/hal-00930837}

Submitted on 1 Jan 2012

HAL is a multi-disciplinary open access archive for the deposit and dissemination of scientific research documents, whether they are published or not. The documents may come from teaching and research institutions in France or abroad, or from public or private research centers.
L'archive ouverte pluridisciplinaire HAL, est destinée au dépôt et à la diffusion de documents scientifiques de niveau recherche, publiés ou non, émanant des établissements d'enseignement et de recherche français ou étrangers, des laboratoires publics ou privés. 


\title{
Climatic response of ring width and maximum latewood density of Larix sibirica in the Altay Mountains, reveals recent warming trends
}

\author{
Feng Chen • Yu-jiang Yuan • Wen-shou Wei • \\ Zi-ang Fan • Tong-wen Zhang • Hua-ming Shang • \\ Rui-bo Zhang $\cdot$ Shu-long Yu $\cdot$ Chun-rong Ji $\cdot$ Li Qin
}

Received: 17 May 2011 / Accepted: 25 January 2012 / Published online: 24 February 2012

(C) INRA / Springer-Verlag France 2012

\begin{abstract}
- Introduction Siberian larch (Larix sibirica) is a highly climate sensitive species. Presently, the Altay Mountains is covered by widespread forests dominated by Siberian larch and thus has a great potential for dendroclimatological studies. However, tree-ring network of the Altay Mountains has not yet been well developed. The development of the new chronologies and the knowledge about the influence of climatic variables on tree growth is needed.

- Method X-ray densitometric techniques were applied to obtain ring width (RW) and maximum latewood density (MXD) of Siberian larch from two upper tree line sites in the Altay Mountains, China. Climatic responses in ring
\end{abstract}

\section{Handling Editor: Matthias Dobbertin}

Contribution of the co-authors Feng Chen (first author), Yu-jiang Yuan (corresponding author), Wen-shou Wei, Zi-ang Fan, Tong-wen Zhang, Hua-ming Shang, Rui-bo Zhang, Shu-long Yu, Chun-rong Ji, Li Qin: sampling and experiment.

F. Chen $\cdot$ Y.-j. Yuan $(\bowtie) \cdot$ W.-s. Wei $\cdot$ Z.-a. Fan $\cdot$ T.-w. Zhang $\cdot$ H.-m. Shang $\cdot$ R.-b. Zhang $\cdot$ S.-l. Yu $\cdot$ C.-r. Ji $\cdot$ L. Qin

Key Laboratory of Tree-ring Physical and Chemical Research of China Meteorological Administration, China Meteorological

Administration, Institute of Desert Meteorology,

46 Jianguo Road,

Urumqi 830002, China

e-mail: yuanyuj5502@sina.com

F. Chen · Y.-j. Yuan • W.-s. Wei · Z.-a. Fan • T.-w. Zhang •

H.-m. Shang $\cdot$ R.-b. Zhang $\cdot$ S.-l. Yu $\cdot$ C.-r. Ji $\cdot$ L. Qin

Xinjiang Laboratory of Tree Ring Ecology, China Meteorological

Administration, Institute of Desert Meteorology,

46 Jianguo Road,

Urumqi 830002, China widths and maximum latewood densities from the Altay Mountains (China, Russia, and Mongolia) were investigated by simple correlation analyses. To assess the common growth forces among the individual sites of the Altay Mountains, simple correlation, principal component analyses, and spatial correlation analysis were applied over the common period of the chronologies.

- Results Ring width and maximum latewood density increases with decreasing precipitation, increasing temperature from late spring to late summer during the growing season. Based on the results of principal component analyses and spatial correlation analysis, summer temperature (June-July) is the most important forces on the Siberian larch growth of the Altay Mountains. The growth of Siberian larch in the Altay Mountains captures the current warming trend. The growth of Siberian larch did not clearly lose its sensitivity under most recent warming in our study areas.

- Conclusions The new MXD chronologies is presently the longest, absolutely dated, tree-ring density record yet developed from China. The climate response analysis shows that the RW and MXD of Siberian larch have strong responses to temperature in the growing season. Thus, MXD and RW of Siberian larch provides the best information for climate reconstruction in the warm season. Tree-rings of Siberian larch allow detecting the recently observed warming trend and putting it into the long-term climatic context in the Altay Mountains, due to the strong growth sensitivity to temperature change.

Keywords Altay Mountains - Densitometric techniques . Larix sibirica $\cdot$ Ring width $\cdot$ Maximum latewood density . Climatic response 


\section{Introduction}

The Altay Mountains is one of the largest mountain system ranges in Central Asia, where Russia, China, Mongolia, and Kazakhstan come together and where the rivers Irtysh and $\mathrm{Ob}$ have their sources. The northwest end of the range is at $52^{\circ} \mathrm{N}$ and between $80^{\circ}$ and $90^{\circ} \mathrm{E}$ and extends southeast to about $46^{\circ} \mathrm{N}$, where it gradually becomes lower and merges into the high plateau of the Gobi Desert. It plays an important role in the climate and ecosystem of Central and North Asia. Presently, the region is covered by widespread forests dominated by various coniferous species and thus has a great potential for dendroclimatological studies.

Siberian larch (Larix sibirica) is one of the dominant species in the Altay Mountains, and it often reaches heights of up to $20 \mathrm{~m}$ and ages of around 350 years. The species is common in the subalpine forest and at lower altitudes in areas with wet soils. Its distribution extends from Mongolia to east Kazakhstan and Siberia. Siberian larch is a highly climate-sensitive species. In strongly exposed locations, it may be no bigger than a shrub. Several tree-ring chronologies of Siberian larch, as climatic proxy records, have been developed from the Altay Mountains in recent decades (Ovtchinnikov et al. 2000; Briffa et al. 2002; Frank et al. 2007; Myglan et al. 2008; Loader et al. 2010; Dulamsuren et al. 2010; Sidorova et al. 2011; Chen et al. 2011). In the course of these studies, growth-climate relationships in different regions and across environmental gradients were evaluated (Frank et al. 2007; Dulamsuren et al. 2010; Chen et al. 2011). However, the Altay Mountains covers a large area and regional climate conditions are far from uniform but vary considerably according to topographic conditions. To improve our understanding of tree-rings as proxies for large-scale climate reconstruction and to estimate the ecological responses of Siberian larch to climate change, profound knowledge about the influence of climatic variables on tree growth is needed.

With their high resolution and reliability, tree-ring widths provide one of the best sources of proxy information about past environmental and climatic changes. However, much of the climate information contained within the rings had been overlooked based on ring-width measurements only. Using $\mathrm{X}$-ray densitometric techniques, other measurements are possible, such as earlywood width, latewood width, maximum latewood density, minimum earlywood density and average earlywood density. Maximum latewood density (MXD) has proven particularly useful as a proxy for warm season temperatures (Briffa et al. 1992; Davi et al. 2003; Wilson and Luckman 2003; Bräuning and Mantwill 2004; D'Arrigo et al. 2004; Grudd 2008; Büntgen et al. 2008; Fan et al. 2009; Wang et al. 2009). Compared with other regions, such as Europe Alps, Siberia and the northern forests of
North America, tree-ring MXD network of the Altay Mountains has not yet been well developed.

In the present study, new chronologies of ring width (RW) and MXD of Siberian larch trees grown at the upper treeline sites in Altay region (China) were developed. The results in terms of cross-dating, standardization, and apparent climatic responses were used to assess the usefulness of Siberian larch for paleoclimate studies and investigate the common driving forces on the Siberian larch growth of the Altay Mountains with the chronologies of Siberian larch from other countries.

\section{Materials and methods}

\subsection{Study area and climate}

The study areas are located in the Altay Mountains (Fig. 1), with a typical cold continental climate. Mean annual temperature is $1.1^{\circ} \mathrm{C}$ while the annual sum of precipitation is $362.8 \mathrm{~mm}, 73 \%$ of which fall during the growing season from April-September. At the upper tree line of the Altay Mountains, the climate is characterized by short cool summers and long and cold winters with considerably higher precipitation in summer. During the winter season, continental air masses of the Siberian high (Asian winter monsoon) dominate and lead to very cold and dry conditions with occasional surges of dry continental polar air from northwesterly directions. The Altay Mountains is covered by snow and ice for six months each year. The dominant tree species in the study areas are L. sibirica and Picea obovata. Soils are mainly brown coniferous forest soil (Fig. 2).

\subsection{New chronology development}

During the 2009-2010 summer field seasons, two Siberian larch sites with little evidence of fire or human disturbance, Kelan River (Altay, site code KLD) and Zuolesa (Qinghe, site code ZLS), were sampled in Altay region, China. To minimize non-climatic effects on tree growth, we only sampled trees without obvious injury or disease. All trees were sampled nondestructively at breast height using the increment borers. Most trees were sampled with two $5 \mathrm{~mm}$ core and two $12 \mathrm{~mm}$ core. In combination, the two sites provide 100 cores $(5 \mathrm{~mm})$ and 74 cores $(12 \mathrm{~mm})$ taken from 50 trees. Site information, including latitude, longitude, slope, and tree number, is listed for each of the sites in Table 1. All samples were processed for RW and the $12 \mathrm{~mm}$ samples from two sites were also processed for MXD.

Conventional techniques of dendrochronology were employed in chronology development (Fritts 1976; Cook and Kairiukstis 1990). The $5 \mathrm{~mm}$ cores were mounted and prepared following standard procedures (Fritts 1976) and 
Fig. 1 Location map of sampling sites and meteorological stations

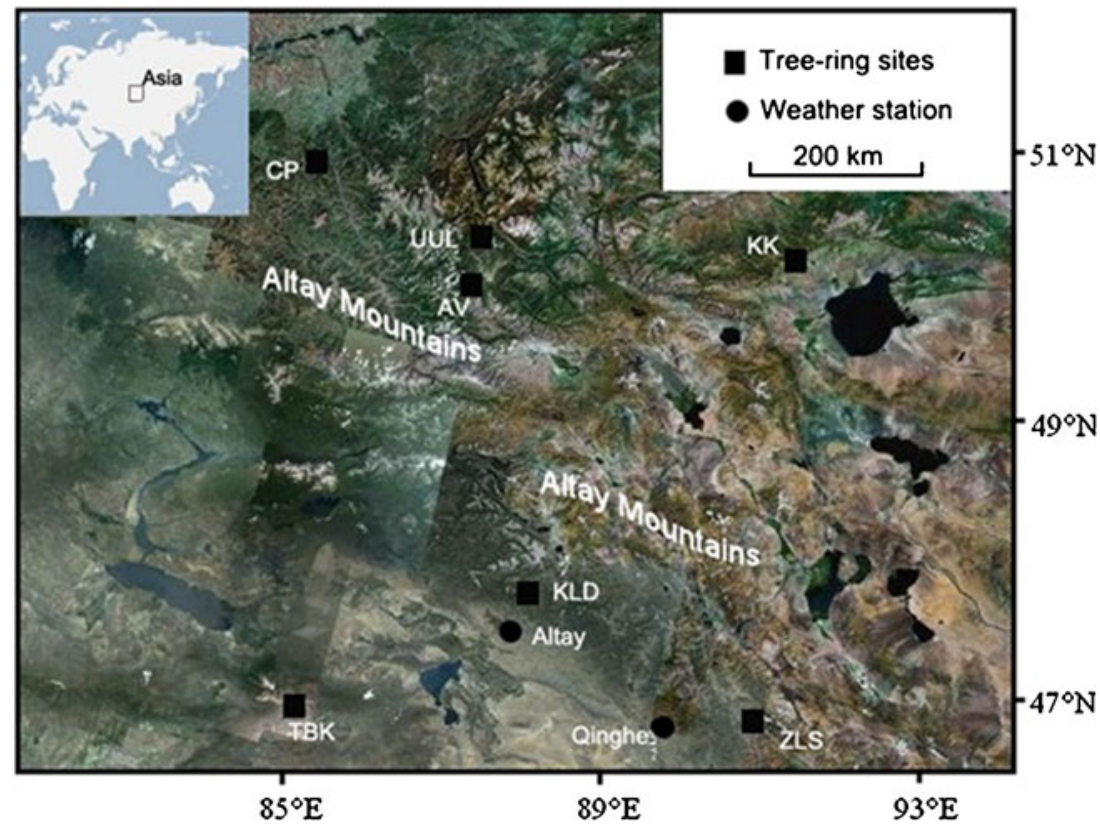

ring widths measured to the nearest $0.001 \mathrm{~mm}$ using a Velmex measuring system. Extraction of volatiles of the $12 \mathrm{~mm}$ cores was performed by hot water and alcohol solution. The $12 \mathrm{~mm}$ cores were cut transversely into strips of $1 \pm 0.02 \mathrm{~mm}$ in thickness with twin-bladed saw (DENDRO-CUT 2003). The strips were oven-dried and subjected to X-ray analysis. These X-ray radiographs were scanned by DENDRO-2003 tree-ring workstation. To obtain good measurements, the steps described by Schweingruber et al. (1978) were adopted. The boundary between earlywood and latewood was set for each ring at $50 \%$ of the difference between maximum and minimum density. Program COFECHA (Holmes 1983) was used for controlling cross-matching quality of the different series.
The statistical cross dating of $12 \mathrm{~mm}$ cores done by the program COFECHA was always visually verified against the image loaded in DENDRO-2003. Each series was standardized (detrended) using the program ARSTAN (Cook and Kairiukstis 1990), in order to remove non-climatic factors. Conservative detrending methods (negative exponential function) were used to generate both RW and MXD chronologies in order to retain low-frequency information (Cook 1985). We used the RW and MXD standard chronologies for the analysis, which contains the common variations among the individual tree core series and retains low through high-frequency common variance, presumably in response to climate (Cook 1985).
Fig. 2 The upper treeline sites within the Altay Mountains, characterized by wide talus slopes and open larch forests

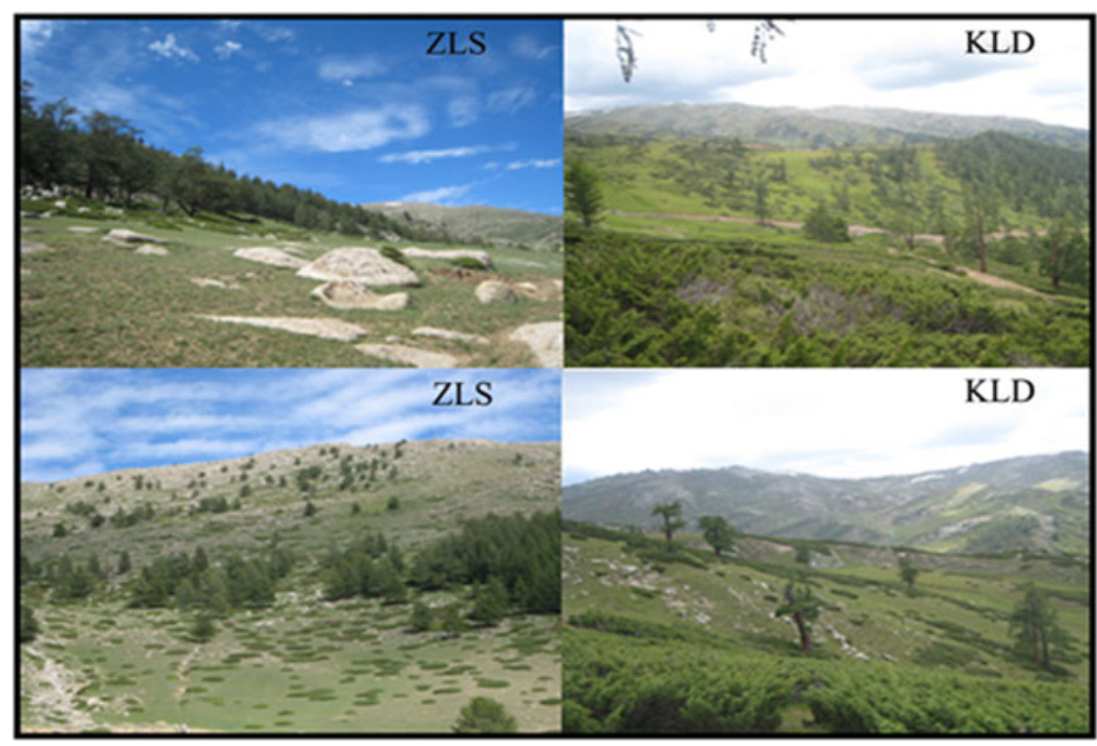


Table 1 Site information for standardized tree-ring chronologies

\begin{tabular}{|c|c|c|c|c|c|}
\hline Tree-ring site & Lat/long & Elevation $(\mathrm{m})$ & Aspect & Slope & $5 \mathrm{~mm}$ core $/ 12 \mathrm{~mm}$ core/tree number \\
\hline KLD & $47^{\circ} 54^{\prime} \mathrm{N} / 88^{\circ} 22^{\prime} \mathrm{E}$ & $2,350-2,400$ & NW & $10-15^{\circ}$ & $52 / 26 / 26$ \\
\hline ZLS & $46^{\circ} 43^{\prime} \mathrm{N} / 90^{\circ} 57^{\prime} \mathrm{E}$ & $2,400-2,500$ & $\mathrm{~N}$ & $5-15^{\circ}$ & $48 / 48 / 24$ \\
\hline TBK & $46^{\circ} 57^{\prime} \mathrm{N} / 85^{\circ} 06^{\prime} \mathrm{E}$ & $2,190-2,400$ & $\mathrm{~N}$ & $5-35^{\circ}$ & $149 / 59 / 73$ \\
\hline $\mathrm{CP}^{\mathrm{a}}$ & $51^{\circ} 00^{\prime} \mathrm{N} / 85^{\circ} 38^{\prime} \mathrm{E}$ & 1450 & & & \\
\hline $\mathrm{UUL}^{\mathrm{a}}$ & $50^{\circ} 29^{\prime} \mathrm{N} / 87^{\circ} 39^{\prime} \mathrm{E}$ & 2150 & & & \\
\hline $\mathrm{AV}^{\mathrm{a}}$ & $50^{\circ} 25^{\prime} \mathrm{N} / 87^{\circ} 35^{\prime} \mathrm{E}$ & 2000 & & & \\
\hline $\mathrm{KK}^{\mathrm{b}}$ & $49^{\circ} 55^{\prime} \mathrm{N} / 91^{\circ} 34^{\prime} \mathrm{E}$ & 2500 & & & \\
\hline
\end{tabular}

KLD Kelan River, ZLS Zuolesa, TBK Tiebuke, CP Ceminsky Pass, UUL Ust Ulagan Lake, AV Aktasch Valley, KK Khalzan Khamar

${ }^{a}$ The chronologies, developed by Dr. F.H. Schweingruber, was obtained from the International Tree-Ring Data Bank, through their web site: http:// www.ncdc.noaa.gov/paleo/treering.html

${ }^{\mathrm{b}}$ The chronologies, developed by Dr. G.C. Jacoby, was obtained from the International Tree-Ring Data Bank

\subsection{Meteorological data and statistical analysis}

To provide a more regional climate signal, the gridded monthly instrumental precipitation (and temperature data) was obtained from the Climatic Research Unit (CRU), East Anglia, UK (http://www.cru.uea.ac.uk) for the Altay Mountains for 1901-2006 (averaged over 45-53 ${ }^{\circ} \mathrm{N}, 80-$ $90^{\circ} \mathrm{E}$ ). Instrumental climate records of Altay (1954-2009) and Qinghe (1961-2009) were obtained from the China National Climatic Data Center. Some tree-ring RW and MXD chronologies of Siberian larch in Mongolia and Russia were obtained from the International Tree-Ring Data Bank.

The relationships between tree-ring indices and the climatic data were analyzed using the program DENDROCLIM2002 (Biondi and Waikul 2004). As the growth of tree may be affected not only by the climatic conditions of the current growing season but also by those of the previous growing season (Fritts 1976; Chen et al. 2010), both the previous and the current growing seasons were included in the climate response analysis. The climate data used for the analysis included monthly mean temperature and total monthly precipitation over a span of 15 months (previous July to current September). To assess the common growth forces among the individual sites of the Altay Mountains, spatial correlation analysis and principal component analyses (PCA) were applied over the common period of the chronologies (16201994).

\section{Results}

3.1 The characteristics of tree-ring chronologies

After obtaining the tree-ring measurements, the cross dating of ring width data was checked by the program COFECHA first. The MXD data were compared to RW cross-dating results. Table 2 gives the general statistics of the tree-ring parameters from COFECHA. The mean correlation of the individual cores (with master) ranged from 0.571 to 0.709 . The highest mean correlation is RW (Zuolesa) and the lowest one is MXD (Kelan River). The high correlation indicates good cross dating between sequences. The firstorder autocorrelation ranged from 0.408 to 0.723 . This implies that the influence factors (i.e., climate conditions, stand development and insect defoliators, etc.) that cause a ring to be narrow (or wide) in one year tend to carry over their effect on the growth of the following year.

The statistics of standard chronologies is given in Table 3. Ring width chronologies exhibit relatively high mean sensitivities (0.174-0.198) and standard deviations (0.192-0.248). These data indicate rather immoderate interannual variations in the ring-width series. The mean correlations between trees $(0.301-0.503)$ and variances in the first eigenvector (39.7-60.5\%) indicate that the growth of different trees was responding to common factors. The MXD indices exhibit low year-to-year variability, as emphasized by the low mean sensitivities $(0.072-0.074)$ and the
Table 2 The statistics results of the Siberian larch tree-ring parameters from program COFECHA

$R W$ ring width, $M X D$ maximum latewood density

\begin{tabular}{lcccc}
\hline Type of parameter & $\begin{array}{c}\text { Mean correlation } \\
\text { with master }\end{array}$ & $\begin{array}{c}\text { Standard } \\
\text { deviation }\end{array}$ & Auto-correlation & Mean sensitivity \\
\hline RW (Kelan River) & 0.612 & 2.791 & 0.687 & 0.255 \\
RW (Zuolesa) & 0.709 & 2.844 & 0.723 & 0.282 \\
MXD (Kelan River) & 0.571 & 1.098 & 0.408 & 0.116 \\
MXD (Zuolesa) & 0.622 & 1.295 & 0.476 & 0.130 \\
\hline
\end{tabular}


Table 3 Summary of statistics for ring-width and maximum latewood density standard chronologies of Siberian larch of the two sites in the Altay Mountains, China

\begin{tabular}{llllll}
\hline & \multicolumn{2}{l}{ Ring width } & & \multicolumn{2}{l}{ Maximum latewood density } \\
\cline { 2 - 3 } & Kelan River & Zuolesa & & Kelan River & Zuolesa \\
\hline Chronology period & $1481-2010$ & $1563-2009$ & & $1488-2009$ & $1563-2008$ \\
The period with an EPS of at least 0.85 & $1505-2010$ & $1580-2009$ & & $1531-2009$ & $1580-2008$ \\
Mean sensitivity & 0.174 & 0.198 & & 0.074 & 0.072 \\
Standard deviation & 0.192 & 0.248 & & 0.075 & 0.080 \\
First-order autocorrelation & 0.420 & 0.569 & & 0.242 & 0.371 \\
Mean correlation between trees & 0.301 & 0.385 & & 0.503 & 0.411 \\
Signal-to-noise ratio & 14.801 & 28.690 & & 8.099 & 15.614 \\
Variance in first eigenvector $(\%)$ & 39.7 & 46.6 & & 60.5 & 51.4 \\
\hline
\end{tabular}

standard deviations $(0.075-0.080)$. These low values of MXD were found in the previous reports (Schweingruber et al. 1978; Cleaveland 1986; Xiong et al. 1998). In general,
MXD is associated with a higher correlation among trees than ring width (Schweingruber et al. 1978; Cleaveland 1986). Mean correlations between trees (0.411-0.503) for
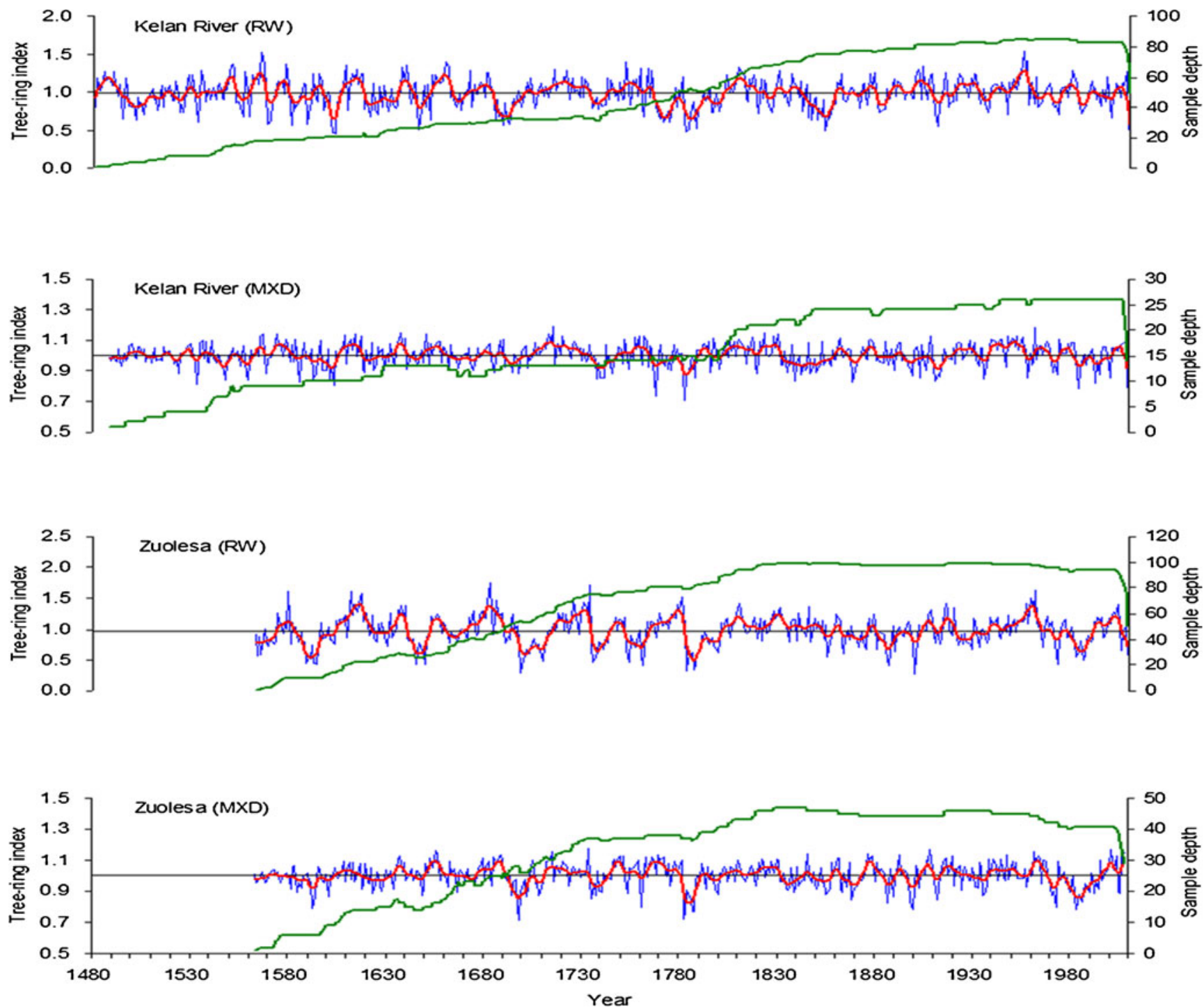

Fig. 3 Plot of new ring width and maximum latewood density standard chronologies of Siberian larch from the Altay Mountains and the sample size. Thin line represents annual values; the thick line was smoothed with a 10 -year low-pass filter 
Table 4 Cross-correlations between the different ring width chronologies for the common time interval 1620-1994

\begin{tabular}{|c|c|c|c|c|c|c|c|}
\hline & Khalzan Khamar & Ceminsky Pass & Aktasch Valley & Ust Ulagan Lake & Kelan River & Zuolesa & Tiebuke \\
\hline Khalzan Khamar & 1.000 & & & & & & \\
\hline Ceminsky Pass & $0.442^{\mathrm{b}}$ & 1.000 & & & & & \\
\hline Aktasch Valley & $0.228^{\mathrm{b}}$ & $0.338^{\mathrm{b}}$ & 1.000 & & & & \\
\hline Ust Ulagan Lake & $0.350^{\mathrm{b}}$ & $0.562^{\mathrm{b}}$ & $0.322^{\mathrm{b}}$ & 1.000 & & & \\
\hline Kelan River & $0.245^{\mathrm{b}}$ & $0.301^{\mathrm{b}}$ & $0.195^{\mathrm{b}}$ & $0.356^{\mathrm{b}}$ & 1.000 & & \\
\hline Zuolesa & $0.247^{\mathrm{b}}$ & $0.304^{\mathrm{b}}$ & 0.084 & $0.270^{\mathrm{b}}$ & $0.382^{\mathrm{b}}$ & 1.000 & \\
\hline Tiebuke & $0.235^{\mathrm{b}}$ & $0.129^{\mathrm{b}}$ & -0.001 & $0.259^{\mathrm{b}}$ & $0.262^{\mathrm{b}}$ & $0.163^{\mathrm{a}}$ & 1.000 \\
\hline $\mathrm{PC} \# 1_{\mathrm{RW}}$ & $0.650^{\mathrm{b}}$ & $0.761^{\mathrm{b}}$ & $0.483^{\mathrm{b}}$ & $0.762^{\mathrm{b}}$ & $0.633^{\mathrm{b}}$ & $0.558^{\mathrm{b}}$ & $0.415^{\mathrm{b}}$ \\
\hline
\end{tabular}

${ }^{\text {a }}$ Significant at the $5 \%$ level

${ }^{\mathrm{b}}$ Significant at the $1 \%$ level

MXD in the Altay Mountains are also higher than those for ring width (0.301-0.385). The high correlation between trees might be the result of strong common signals in MXD of Siberian larch.

In order to estimate the reliability of the tree-ring chronologies, the expressed population signal (EPS) and $R_{\text {bar }}$ were calculated using program ARSTAN (Cook and Kairiukstis 1990). EPS evaluates the relationship between the sample size of a chronology and the common variance or "signal" within a chronology (Wigley et al. 1984). The running mean EPS value (30-year moving window with 5year overlaps) is 0.968 over the entire RW common period (ranging from 0.864 to 0.991 ) and 0.935 over the entire MXD common period (ranging from 0.668 to 0.976 ). The mean $R_{\text {bar }}$ for RW and MXD are 0.443 and 0.468 , respectively. They are the longest records now available in the Altay Mountains of China, ranging from 446 to 530 years in duration. Generally, an EPS value of 0.85 or greater is considered a rough cut-off point for an acceptable level. The MXD records (Kelan River) are also the longest MXD records in China now, based on this threshold value (Fig. 3).

The seven RW chronologies of Siberian larch are correlated significantly among each other (Table 4). The six MXD chronologies of Siberian larch also display significant inter-site correlations (Table 5), with the highest correlation found between Aktasch Valley (AV) and Ust Ulagan Lake (UUL; $r=0.71, p<0.01$ ). PCA revealed that the $\mathrm{PC} \# 1_{\mathrm{RW}}$ and $\mathrm{PC} \# 1_{\mathrm{MXD}}$ have eigenvalues $>2$ and account for $38.55 \%$ and $57.44 \%$ of the total variance, respectively (Fig. 4). The correlation coefficient between the $\mathrm{PC} \# 1_{\mathrm{RW}}$ and $\mathrm{PC} \# 1_{\mathrm{MXD}}$ is $0.611(p<0.001)$.

\subsection{Climate response analysis}

The simple correlation analysis reveals that RW chronologies are related mainly to summer temperatures (Fig. 5). RW (Tiebuke, Kelan River, and Ust Ulagan Lake) is positively correlated with temperature of the current June, with the significance at $p<0.01$ for both the response function and correlation analyses. RW (Khalzan Khamar, Ceminsky Pass) has a strong positive relationship to the temperatures (June-July). The strong negative relationship between RW and precipitation of the current July is found at the highelevation sites (Khalzan Khamar, Kelan River, Ceminsky Pass, and Tiebuke).

The MXD chronologies at the six sites of Siberian larch show clear common responses to climatic factors during the warm season (Fig. 6). We found strong positive correlations between MXD and temperature during the warm season. However, the effective months differ among the sites: MXD (Zuolesa, Tiebuke, Ceminsky Pass, Ust Ulagan Lake, and
Table 5 Cross correlations between the different maximum latewood density chronologies for the common time interval 1620-1994

${ }^{a}$ Significant at the $1 \%$ level

\begin{tabular}{lllllll}
\hline & $\begin{array}{l}\text { Ceminsky } \\
\text { Pass }\end{array}$ & $\begin{array}{l}\text { Aktasch } \\
\text { Valley }\end{array}$ & $\begin{array}{l}\text { Ust Ulagan } \\
\text { Lake }\end{array}$ & Kelan River & Zuolesa & Tiebuke \\
\hline Ceminsky Pass & 1.000 & & & & & \\
Aktasch Valley & $0.474^{\mathrm{a}}$ & 1.000 & & & \\
Ust Ulagan Lake & $0.509^{\mathrm{a}}$ & $0.713^{\mathrm{a}}$ & 1.000 & & & \\
Kelan River & $0.505^{\mathrm{a}}$ & $0.548^{\mathrm{a}}$ & $0.561^{\mathrm{a}}$ & 1.000 & & \\
Zuolesa & $0.458^{\mathrm{a}}$ & $0.405^{\mathrm{a}}$ & $0.520^{\mathrm{a}}$ & $0.622^{\mathrm{a}}$ & 1.000 & \\
Tiebuke & $0.374^{\mathrm{a}}$ & $0.365^{\mathrm{a}}$ & $0.406^{\mathrm{a}}$ & $0.466^{\mathrm{a}}$ & $0.408^{\mathrm{a}}$ & 1.000 \\
PC\#1 & $0.725^{\mathrm{a}}$ & $0.779^{\mathrm{a}}$ & $0.826^{\mathrm{a}}$ & $0.821^{\mathrm{a}}$ & $0.750^{\mathrm{a}}$ & $0.641^{\mathrm{a}}$ \\
\hline
\end{tabular}


Fig. 4 The PC\#1 of RW and MXD. Thin line represents annual values; the thick line was smoothed with a 10 -year lowpass filter. The period of warming are shaded in grey

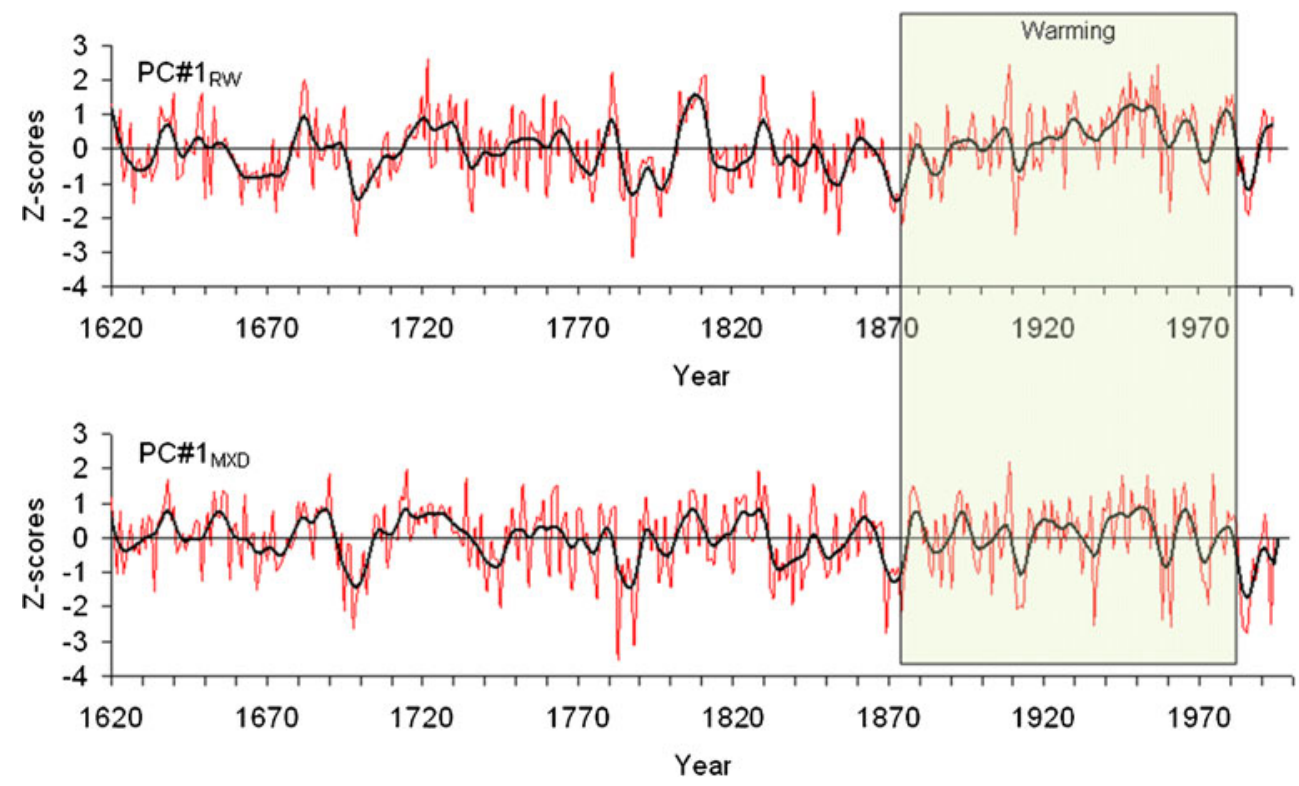

Kelan River) is correlated with temperatures of May, June, and July, and that at low-elevation site (Ceminsky Pass) is correlated with those of May, June, July, August, and September. The MXD chronologies of Siberian larch
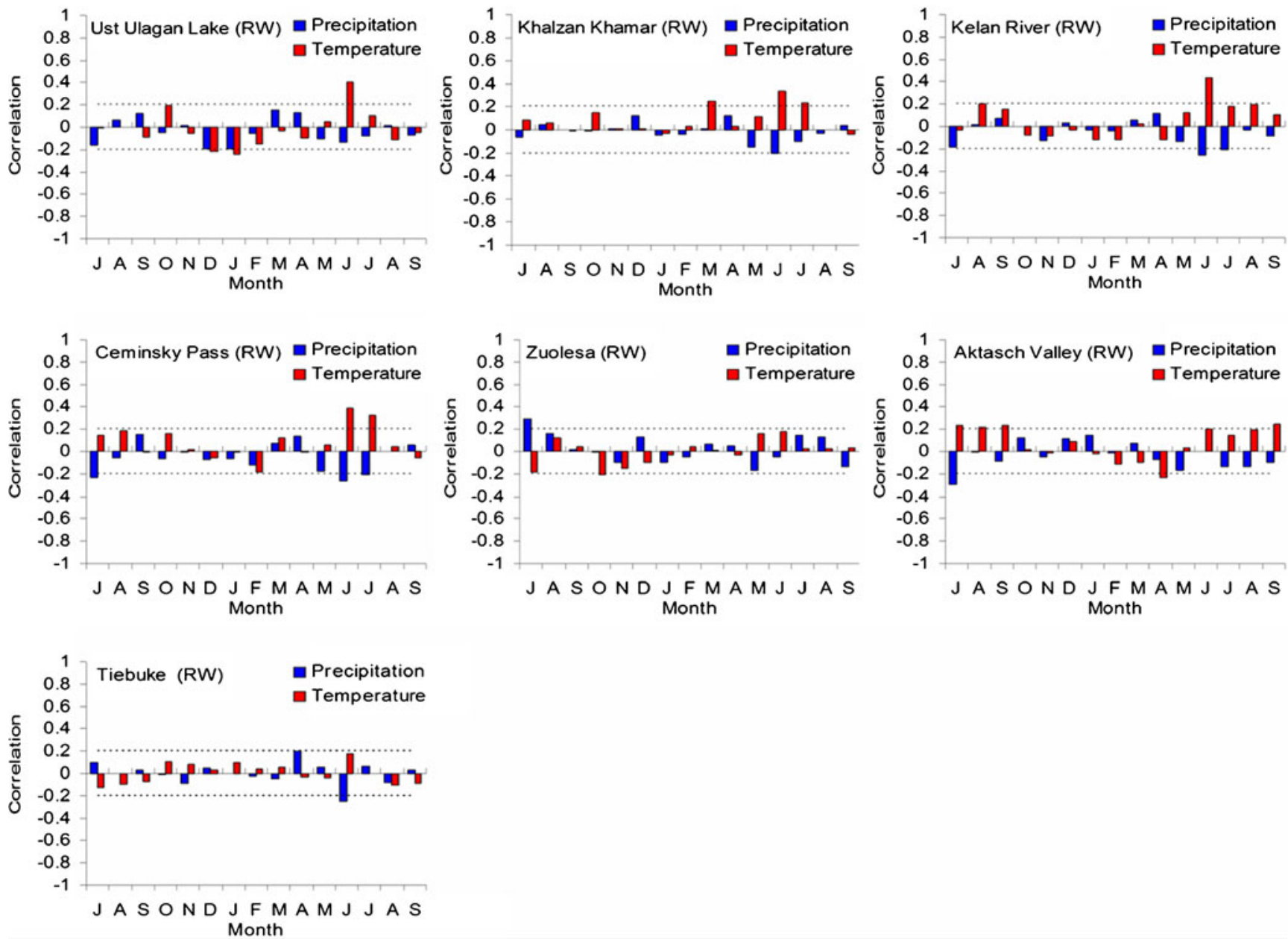

Fig. 5 Climatic responses of tree-ring width chronologies of Siberian larch in the Altay Mountains, obtained from simple correlations (bars). The dot lines indicate significant variables $(p<0.05)$ 

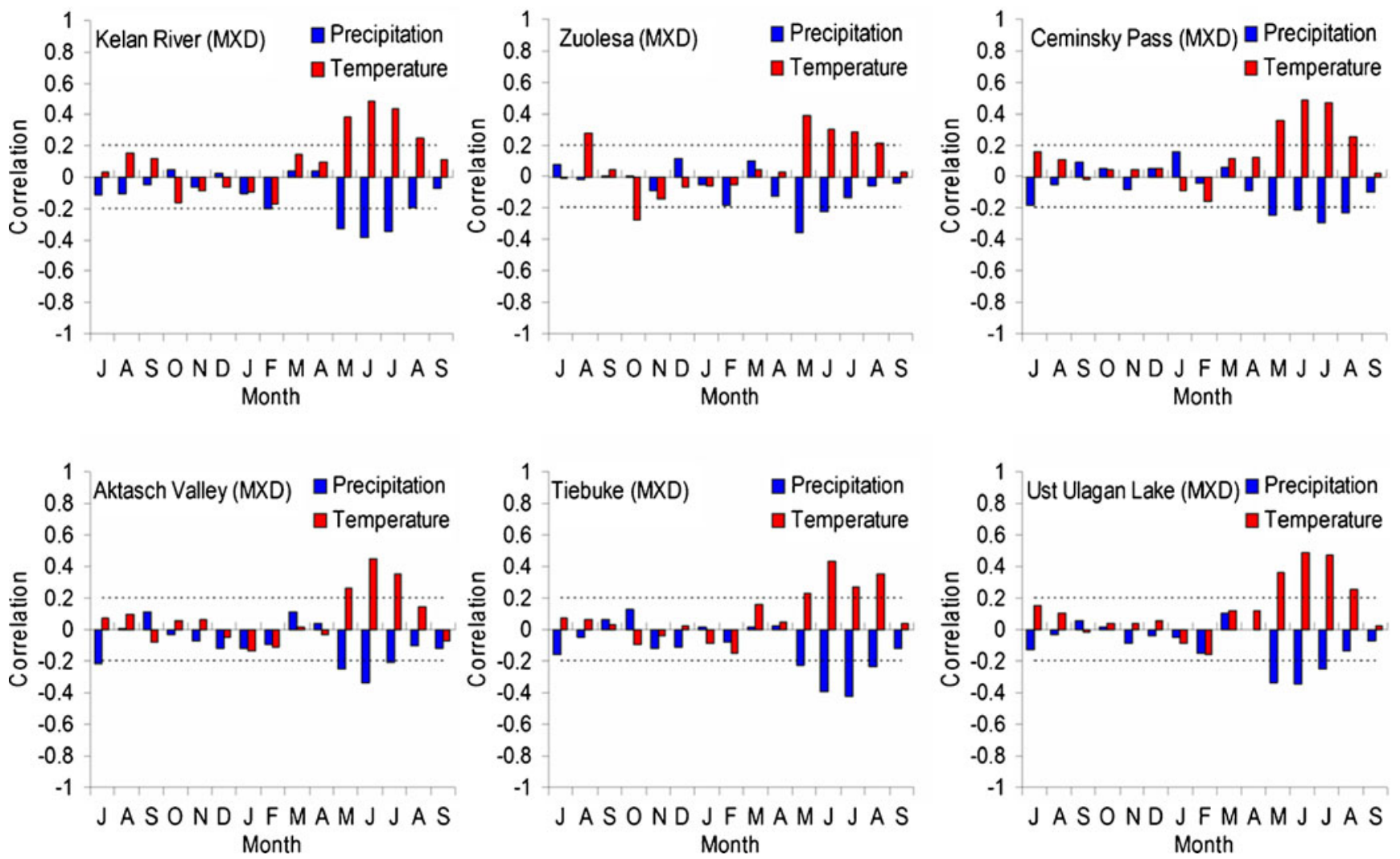

Fig. 6 Climatic responses of tree-ring MXD chronologies of Siberian larch in the Altay Mountains, obtained from simple correlations (bars). The dot lines indicate significant variables $(p<0.05)$

(Ceminsky Pass, Aktasch Valley, Ust Ulagan Lake, Tiebuke, Kelan River, and Zuolesa) are negatively correlated with the precipitation (May-July).

To investigate the common growth forces, we screened $\mathrm{PC} \# 1_{\mathrm{RW}}$ and $\mathrm{PC} \# 1_{\mathrm{MXD}}$ in correlation analysis with the seasonal combinations of temperatures and precipitation from previous July to current September. The strongest correlation was found between the PCs and June-July temperature.

To demonstrate that the relationship between tree growth and recent warming trends, we conducted the correlations between the new chronologies of the Altay region and instrumental climate records of Qinghe and Altay. The new chronologies ate highly correlated with June-July temperature, especially MXD (Fig. 7).

\section{Discussion}

\subsection{Climate-growth response}

Dulamsuren et al. (2011) found that radial growth of $L$. sibirica growing at low-elevation sites, northern Mongolia was positively associated with precipitation during the growing season. However, in this case, the negative responses of RW and MXD of L. sibirica to precipitation at the sites suggest that the growth of L. sibirica is not limited by moisture stress. Contrary to other arid and semi-arid areas of Central Asia, there is relatively abundant precipitation in the Altay Mountains. The precipitation at the upper tree line of the Altay Mountains is often fall in the form of snow. As shown in Fig. 2, the mountain peaks near the upper tree line are still covered by snow during summer. High negative correlation $(r=-0.625, p<0.001)$ was found between June-July temperature and May-July precipitation. Enhanced cloudiness and rainfall may lead to temperature drop. Wet and cold climatic conditions have a strong depression in tree growth of $L$. sibirica. However, the response time to precipitation differs among the sites. The differences in responses might have been due to the local climate conditions.

The growth of Siberian larch in the Altay Mountains occurs for almost 6 months, from April to September. The period of growth corresponds to the months that reveal a significant correlation between RW/MXD and temperature. From the physiological perspective, tree-ring formation consists of three stages: cell division, cell enlargement, and cell-wall thickening (Larson 1967). Cell division and lengthening 

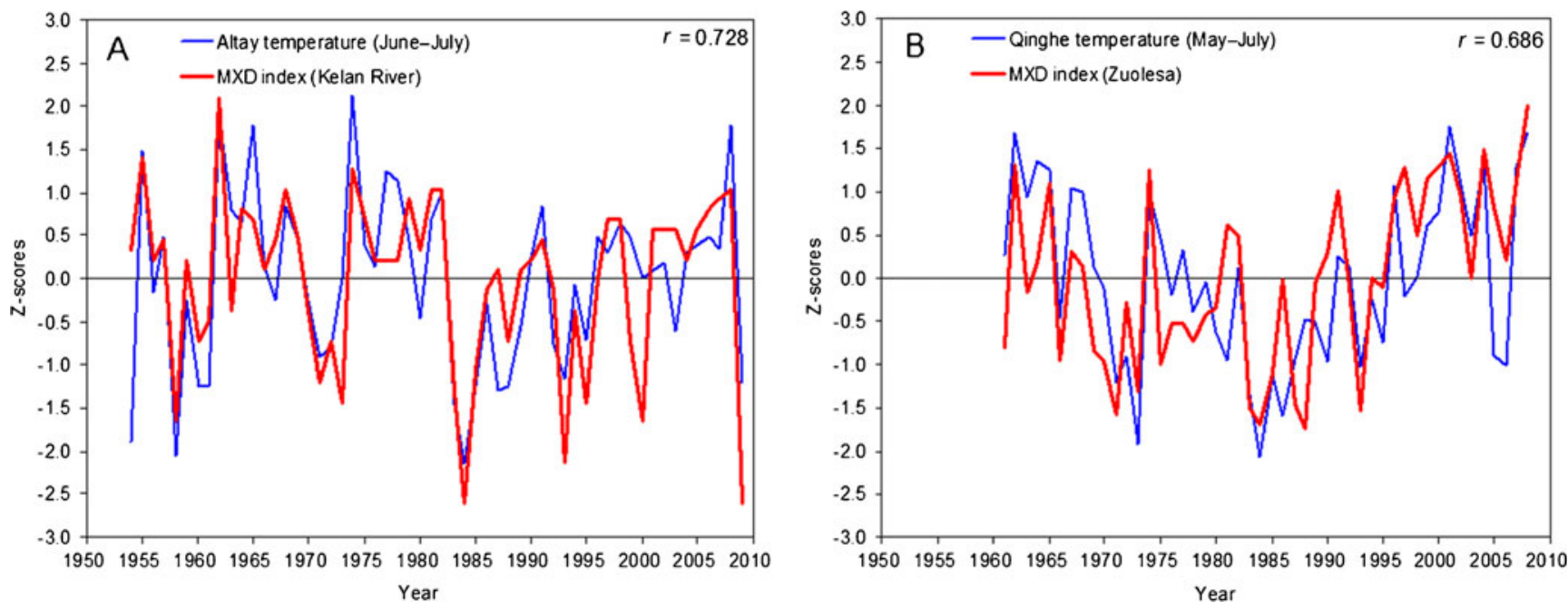

Fig. 7 a Comparison of the MXD (KLD) and the actual June-July temperature (Altay). b Comparison of the MXD (ZLS) and the actual May-July temperature (Qinghe)

occurred mainly in the early part of growing season, as shown by tree radial enlargement. The positive correlations between RW and the temperature of current summer suggest that the radial growth of Siberian larch in the Altay Mountains is accelerated by high temperatures in the summer. Warm-humid environments of growing season can lead to high radial growth.

MXD is an annual ring parameter based on the highest density of the cells formed at the end of the growing season (Parker and Jozsa 1973; Schweingruber 1988; Davi et al. 2003). Even though cell division ceased at the end of the growing season, the thickening of cell walls of tracheids continued. The climate of late growing season may directly affect the thickening of cell walls of the last-formed cells. The values of MXD are mainly limited by the cold temperature of the late growing season. Thus, it appears that the period of maturation of the last-formed cells corresponds to the months that yield significant correlations between MXD and temperature. On the other hand, the growth of tree may be affected not only by the current climatic conditions of but also by those of the early part of growing season. The climate of the early part of growing season also has a significant impact on the formation of MXD. Previous studies (Schweingruber et al. 1978; Cleaveland 1986; Xiong et al. 1998; D'Arrigo et al. 2004; Büntgen et al. 2008; Fan et al. 2009) also demonstrated the responses of MXD to the warm season temperatures (from spring to late summer). Elevation is also an important factor limiting the growing season length. Maximum latewood density at low altitude (Ceminsky Pass) showed a significant response to temperature for the 5 months (May-September)
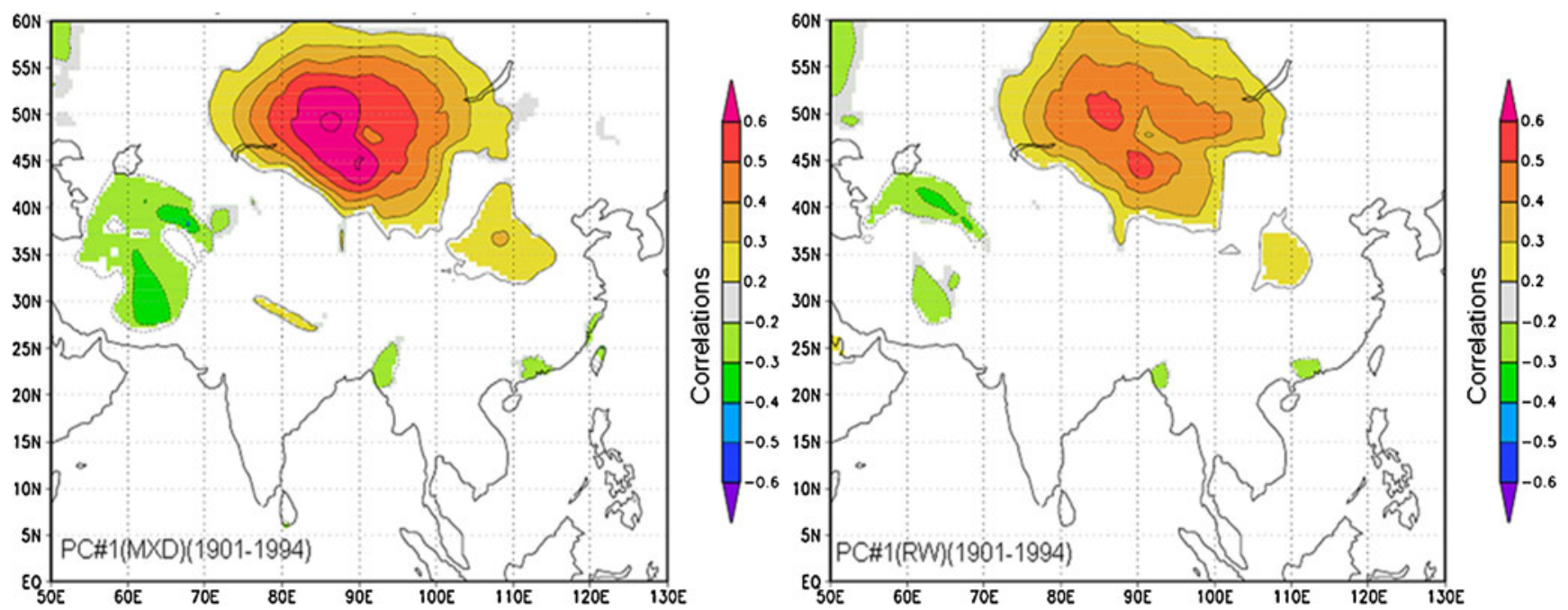

Fig. 8 Spatial correlations between the PC\#1 of MXD/RW and the gridded dataset of surface temperatures (June-July). The analyses were performed using the KNMI climate explorer (Royal Netherlands Meteorological; http://climexp.knmi.nl) 
while for the high elevation sites only temperature was only significant for the 4 months from May to August.

\subsection{Large-scale forces in the Altay Mountains}

High correlation coefficient between the $\mathrm{PC} \# 1_{\mathrm{RW}}$ and $\mathrm{PC} \# 1_{\mathrm{MXD}}$ shows that the growth forces are common among Siberian larch in the Altay Mountains. To investigate the common growth forces in more detail, we conducted spatial correlations between PCs and the updated $0.5 \times 0.5$ gridded June-July temperature of CRU TS3.0 for the period 19011994 by the use of the KNMI climate explorer (http:// climexp.knmi.nl). The results of spatial correlation analysis show that the PC\#1 of RW/MXD correlate $>0.5$ with JuneJuly temperature grid-box data in a large area of Central Asia, with highest correlations occurring in the Altay Mountains (Fig. 8). Despite a complex mountain terrain and spatial differences in local temperature and tree growth, based on the above analysis results, summer temperature (June-July) is the most important forces on the Siberian larch growth of the Altay Mountains.

\subsection{Tree growth and recent warming trends}

The tree-ring data in Siberia and Mongolia neighboring the Altay Mountains revealed the similar rise of temperatures form the mid-nineteenth century (Jacoby et al. 1996; Briffa et al. 2002). The growth of Siberian larch in the Altay Mountains also captures this warming trend (Fig. 4). However, due to chronology length limit, old tree-ring data of the Altay Mountains did not track the most recent abnormal warming (Jones et al. 1998; Mann et al. 1999; Briffa 2000; Esper et al. 2002; D'Arrigo et al. 2006). In the Altay Mountains, new tree-ring data (Kelan River and Zuolesa) show the warming trend in the recent decadal years. Unlike widely reported "divergence problem" in northern forests (Briffa et al. 1998; Vaganov et al. 1999; D'Arrigo et al. 2008). The growth of Siberian larch did not clearly lose its sensitivity under most recent warming in our study areas (Fig. 7). The new chronologies allow detecting the recent warming in a long-term context in the Altay Mountains.

\section{Conclusions}

We have developed four RW and MXD chronologies of Siberian larch at two upper tree ling sites in the Altay Mountains, China. The cross-matching statistics between trees for each parameter are relatively high. The MXD chronology (Kelan River) is presently the longest, absolutely dated, tree-ring density record yet developed from China. The climate response analysis shows that the MXD of Siberian larch can potentially be exploited as indicators for dendroclimatological studies because of their strong responses to temperature in the growing season. While the climatic responses of MXD varied among the sites, RW series were strongly correlated with temperatures during the current summer. Thus, MXD and RW of Siberian larch provides the best information for climate reconstruction in the warm season. PCA and spatial correlation analysis revealed that summer temperature (June-July) is the most important common forces on the Siberian larch growth of the Altay Mountains, and covers the whole region. The sensitivity of recent tree-growth to temperature in the Altay Mountains was not significantly reduced under climate warming. Tree-rings of Siberian larch allow detecting the recently observed warming trend and putting it into the long-term climatic context in the Altay Mountains. Continued work in this direction should enable us to understand better the growth change of Siberian larch under global warming and the past climate variability of the Altay Mountains over long temporal and large spatial scales.

Acknowledgments This work was supported by supported by the National Science Foundation of China (grant no. 40975056, 41071072, and 41005059), the Basic Research Project of Science and Technology Ministry of China (2007FY220200), Meteorology Public welfare Industry Research Special project (GYHY200806011), China Desert Meteorological Science Research Foundation (SQJ2010011). Treering data from some sites was obtained from the NOAA Paleoclimatology International Tree-Ring Data Bank (ITRDB). Particular thanks are extended to Dr. M. Dobbertin and one anonymous reviewer for their valuable suggestions and comments regarding the revision of the manuscript.

\section{References}

Biondi F, Waikul K (2004) DENDROCLIM2002: a C++ program for statistical calibration of climate signals in tree-ring chronologies. Comput Geosci 30:301-311

Bräuning A, Mantwill B (2004) Summer temperature and summer monsoon history on the Tibetan plateau during the last 400 years recorded by tree rings. Geophys Res Lett 31:L24205. doi:10.1029/2004GL020793

Briffa KR (2000) Annual climate variability in the Holocene: interpreting the message of ancient trees. Q Sci Rev 19:87-105

Briffa KR, Jones PD, Schweingruber FH (1992) Tree-ring density reconstructions of summer temperature patterns across western North America since 1600. J Clim 5:735-754

Briffa KR, Schweingruber FH, Jones PD, Osborn T (1998) Reduced sensitivity of recent tree growth to temperature at high northern latitudes. Nature 391:678-682

Briffa KR, Jones PD, Schweingruber FH, Shiyatov SG, Cook ER (2002) Unusual twentieth-century summer warmth in a 1000year temperature record from Siberia. Nature 376:156-159

Büntgen U, Frank DC, Grudd H, Esper J (2008) Long-term summer temperature variations in the Pyrenees. Clim Dyn 31:615-631

Chen F, Yuan Y, Wei W, Yu S, Li Y, Zhang R, Zhang T, Shang H (2010) Chronology development and climate response analysis of Schrenk spruce (Picea Schrenkiana) tree-ring parameters in the Urumqi river basin, China. Geochronometria 36:17-22 
Chen F, Yuan YJ, Wei WS, Wang LL, Yu SL, Zhang RB, Fan ZA, Shang HM, Zhang TW, Li Y (2011) Tree ring density-based summer temperature reconstruction for Zajsan Lake area East Kazakhstan. Int J Climatol. doi:10.1002/joc.2327

Cleaveland MK (1986) Climatic response of densitometric properties in semiarid site tree rings. Tree-Ring Bull 46:13-47

Cook ER (1985) A time series analysis approach to tree-ring standardization. Ph.D. thesis, University of Arizona, Tucson

Cook ER, Kairiukstis LA (1990) Methods of dendrochronology: applications in the environmental sciences. Kluwer, Dordrecht

D'Arrigo RD, Mashig E, Frank D, Jacoby GC, Wilson R (2004) Reconstructed warm season temperatures for Nome, Seward Peninsula Alaska. Geophys Res Let 31:L09202. doi:10.1029/ 2004GL019756

D'Arrigo R, Wilson RJS, Jacoby GC (2006) On the long-term context for late 20th century warming. J Geophys Res 111:D03103. doi:10.1029/2005JD006352

D'Arrigo R, Wilson R, Liepert B, Cherubini P (2008) On the 'divergence problem' in northern forests: a review of the treering evidence and possible causes. Glob Planet Change 60:289-305

Davi N, Jacoby GC, Wiles GC (2003) Boreal temperature variability inferred from maximum latewood density and tree-ring width data, Wrangell Mountain region, Alaska. Quat Res 60:252-262

Dulamsuren $\mathrm{Ch}$, Hauck M, Khishigjargal M, Leuschner HH, Leuschner C (2010) Diverging climate trends in Mongolian taiga forests influence growth and regeneration of Larix sibirica. Oecologia 163:1091-1102

Dulamsuren Ch, Hauck M, Leuschner HH, Leuschner C (2011) Climate response of tree-ring width in Larix sibirica growing in the drought-stressed forest-steppe ecotone of northern Mongolia. Ann For Sci. doi:10.1007/s13595-011-0043-9

Esper J, Cook ER, Schweingruber FH (2002) Low-frequency signals in long tree-ring chronologies for reconstructing past temperature variability. Science 295:2250-2252

Fan ZX, Bräuning A, Yang B, Cao KF (2009) Tree ring density-based summer temperature reconstruction for the central Hengduan Mountains in southern China. Glob Planet Change 65:1-11

Frank DC, Ovchinnikov D, Kirdyanov A, Esper J (2007) The potential for long-term climatic reconstructions in the Central Altay Mountains from living and relict larch. Trace 5:85-96

Fritts HC (1976) Tree Rings and Climate. Academic Press, London

Grudd H (2008) Torneträsk tree-ring width and density AD 500-2004: a test of climatic sensitivity and a new 1500-year reconstruction of north Fennoscandian summers. Clim Dyn 31:843-857

Holmes RL (1983) Computer-assisted quality control in tree-ring dating and measurement. Tree-Ring Bull 44:69-75

Jacoby GC, D'Arrigo RD, Davaajamts T (1996) Mongolian tree rings and 20th century warming. Science 273:771-773
Jones PD, Briffa KR, Barnett TP, Tett SFB (1998) High-resolution palaeoclimatic records for the past millennium: interpretation, integration and comparison with general circulation model control-run temperatures. Holocene 8:455-471

Larson PR (1967) Effects of temperature on the growth and wood formation of ten Pinus resinosa sources. Silvae Genet 16:58 65

Loader NJ, Helle G, Los SO, Lehmkuhl F, Schleser GH (2010) Twentieth-century summer temperature variability in the southern Altai Mountains: a carbon and oxygen isotope study of tree-rings. Holocene 20:1149-1156

Mann ME, Bradley RS, Hughes MK (1999) Northern Hemisphere temperatures during the past millennium-inferences, uncertainties, and limitations. Geophys Res Lett 26:759-762

Myglan VS, Oidupaa OC, Kirdyanov AV, Vaganov EA (2008) 1929year tree-ring chronology for the Altai-Sayan. Region (Western Tuva). Archaeol Ethnol Anthropol Eurasia 36:5-31

Ovtchinnikov D, Adamenko M, Panushkina IA (2000) 1105-year treering chronology in Altai Region and its application for reconstruction of summer temperatures. Geolines 11:121-122

Parker ML, Jozsa LA (1973) X-ray scanning machine for tree-ring width and density analysis. Wood Fiber 5:192-197

Schweingruber FH (1988) Tree rings: basics and applications of dendrochronology. Kluwer Academic Press, Dordrecht

Schweingruber FH, Fritts HC, Bräker OU, Drew LG, Schär E (1978) The X-ray technique as applied to dendroclimatology. Tree-Ring Bull 38:61-91

Sidorova OV, Saurer M, Myglan VS, Eichler A, Schwikowski M, Kirdyanov V, Bryukhanova V, Gerasimova OV, Kalugin IA, Daryin AV, Siegwolf RTW (2011) A multi-proxy approach for revealing recent climatic changes in the Russian Altai. Clim Dyn. doi:10.1007/s00382-010-0989-6

Vaganov EA, Hughes MK, Kirdyanov AV, Schweingruber FH, Silkin PP (1999) Influence of snowfall and melt timing on tree growth in subarctic Eurasia. Nature 400:149-151

Wang LL, Duan JP, Chen J, Huang L, Shao XM (2009) Temperature reconstruction from tree-ring maximum density of Balfour spruce in eastern Tibet, China. Int J Climatol 30:972-979

Wigley TML, Briffa KR, Jones PD (1984) On the average value of correlated time series, with applications in dendroclimatology and hydrometeorology. J Clim Appl Meteorol 23:201-213

Wilson RJS, Luckman BH (2003) Dendroclimatic reconstruction of maximum summer temperatures from upper tree-line sites in interior British Columbia. Holocene 13:853-863

Xiong L, Okada N, Fujiwara T, Ohta S, Palmer J (1998) Chronology development and climate response analysis of different New Zealand pink pine (Halocarpus biformis) tree-ring parameters. Can J For Res 28:566-573 